\title{
The Sources of Raising Money as the Factor Influencing the Level of Financial Literacy and Degree of the Financial Inclusion
}

\author{
Bożena Frączek \\ University of Economics in Katowice, Poland
}

\begin{abstract}
The effectiveness of the financial education may be measured by the level of financial literacy. Repeatedly proven the low level of financial literacy requires the analysis of factors influencing the improving the results of the educational actions. The one of very important factor seems to be the source of raising fund. It influences the attitude toward money and associated risk as well as the motivation to study different financial concepts and mechanisms. The aim of the paper is to examine the influence of the source of money on effectiveness of financial education represented by level of financial literacy as well as by the very closely related degree of financial inclusion.
\end{abstract}

\section{Introduction}

The financial literacy understood as the financial knowledge and skills as well as the financial awareness, patterns and behavior [12] is very important for both individuals and economy as a whole [9] including financial markets [10].

The level of financial literacy is very low all over the world. And although the level of financial literacy is different in particular countries, it is always unsatisfactory, especially in the times of very rapid development of the financial market [13]. This statement refers to people in developing as well as developed countries [6], to poor and rich, to less and more educated [3] [18], to women and men, to all age groups of societies in particular nations and regions [2] [14] [3].

Considering the further functioning of the financial market and its particular segments, worthy of the attention seems to be youth as the potential participants of this market [11].

Today's youth is of particular importance for the future of financial markets, especially if it is taken into account the facts and trends relating to demographic changes, with particular emphasis on the participation of young people and children in the population. It should be noted that the youth (in the world scale) represents the largest cohort of young people that has ever existed and in many countries they are very important part of the population structure. Young people represent an important source of skills, creativity and dynamism that may help the financial market develop, economy grow and become more competitive.

Therefore, young people should be clocked in a special way. It is therefore necessary to recognize more clearly segment of youth as the potential participants of the financial markets.

The scale and range of the participating in the financial world (degree of financial inclusion) depends on level of financial literacy. The most important tool to enhance still unsatisfactory level of financial literacy is effective financial education [12]. The problem is what is the best way to achieve the expected effects in financial education, how to measure it and what factor influence the effective financial education?

There are in the literature published many results of much research on different socio-demographic factors influencing the level of financial literacy and at the same time on the effectiveness of the financial education (the level of financial literacy may be good way to measurement of efficiency of financial education). The mentioned research shows the impact of gander, age, level of income, level and field of learning on the level of the financial knowledge and skills. Men usually achieve higher scores on financial literacy and typically participate more than women in the stock market [1]. Children, youth and the oldest people are less educated then middle-aged adults, therefore the financial literacy and financial inclusion follows an inverted-U shape with respect to age [7]. Many studies have also demonstrated that financial literacy is higher for higher income individuals [4] and that the financial literacy increases together with the years of schooling [8].

There are also other factors that can influence the level of the financial literacy. One of them may be source of raising money. This may be especially noticeable in the case of youth, who may achieve income from many different sources.

The type of source as well as less or more considerable efforts in achieving money, determines attitude and belief toward it, toward financial risk etc. The multiplicity of differences in perceived value of money depends on many factors, e.g. different experiences, gender and socio-economic environment. The opinion about money differs among people from different groups such as 
students, trainees, scientists, etc. Working individuals generally hold positive attitude towards money [19]. Money attitude influences not only the actions but also the way of thinking of individuals [17]. Earning money causes the willingness of being smarter about money than in the case of getting money in the form of gifts and pocket money. Money has power to enhance self-esteem and selfconfidence of individual's most likely with simultaneous impact on size and range of participation in the financial markets. And the source of funds and effort to gain money influence the proportion of spending and saving money and at the same time on degree of using the basic financial offers. These, in turn, may contribute to very effective education by practice.

\section{Research problem}

Referring to the presented insights, the objective of the paper is to examine the relationships between the source of achieving the money and effectiveness of financial education. The efficiency of financial education may be measured by the level of financial literacy, by the degree of financial inclusion and also by the more or less rational attitude toward risk refers to money. The following research hypotheses were formulated:

1. The source of achieving money, especially in the meaning of the degree of efforts undertaken, affects the efficiency of financial education.

2. Despite of differences in student money sources, it is the same type of impact of the raising money way on efficiency of financial education.

Therefore, the basic research questions are:

A. What are the main sources of raising funds by youth?

B. Is there relationship between the source of achieving the money and the level of financial literacy of university students?

C. Does the source of raising funds impact on the scale and quality of participating in financial market?

D. Does the source of achieving the money influence the attitude toward investment risk?

E. Does the efforts of the undertaken job influence the motivation to non-formal and informal financial education (e.g. via Internet)?

\section{Methodology}

The two-stages methodology was planned to answer the research questions verify research hypotheses and achieve the research goals.

The first stage covers the study of the academic and non-academic literature refers different and varied sources of money of children and youth as well as their impact on many aspects of their daily life. It is an introduction to the empirical research on the impact the source of money on level of the financial knowledge, skills as well as attitude toward investment risk and degree of financial inclusion among higher education students in Poland.

In the second stage (empirical part of study) there were used the questionnaires directed to 278 Polish students (163 economy students, 116 law students).

The research on the base of the questionnaires has provided a comprehensive set of information about:

- Different sources of money like pocket money, working outside school hours (e.g. holiday job, part-time work), working in a family business, occasional informal jobs, gifts of money from friends or relatives, selling things, full-time work,

- Level of financial literacy and skills. The level of financial knowledge was measured using a set of eight questions refer to basic numeracy, understanding the problem and differences between simple and compound interest, relationship between inflation and return, inflation and prices, risk and return, and the role of diversification in risk reduction. The questions refer to financial knowledge were also used in other coordinated research [22].

- Different scale and range of using basic financial services and products. These questions were used in the research of the World Bank and refer to using the banking account, payment cards, mobile payments as well as saving and investing at the capital markets.

- Attitudes toward financial risk - choice of various options of the real or potential investment portfolio: $50 \%$ bonds and $50 \%$ stocks, more than $50 \%$ bonds and less than $50 \%$ stocks, only bonds, only stocks.

- Some other aspects refer to financial literacy and/or education (e.g. possibilities of using the Internet in education including the financial education by practice).

Each correct answer was given a score of one.

\section{Sources of raising funds by youth}

The analysis of the types of funds sources of young people with their impact on patterns of money management and financial behavior is very important problem that is often neglected in economic research.

There is a very small number of researches on sources of financial funds of children and youth, how they use this money and how it affects different aspects of their daily life. Generally the important are the differences in the consequences of access to money without doing any work and making an effort of work for raising money.

The most popular income of young people funds seems to be the pocket money. There are published 
the results of the few studies on the amounts of pocket money given to children and young people and how they use this money. The research also refers to differences in the amounts of pocket money received by boys and girls and their patterns of consumption or spending money [5]. The concept of an allowance or a pocket money given by parents at regular intervals may be carried out by two ways: for regularly doing chores at home and without having to do any chores. This concept of an allowance or pocket money given at regular intervals may be used by parents to teach children the value of money. But it should be noted, that a lot of parents are supporters of children pocket money for household chores as a better lesson of the value of money.

The next source of the income of children and youth is spare-time jobs usually carry out as the parttime jobs. The research in this area the most often refers to examine the scale of the phenomenon of working students pursuing a full-time education during the school term [16] or during the holidays.

The way of gathering the money influences many aspects of daily life, especially in the case of young people who have many possibilities to achieve the funds. The part-time jobs can influence educational results of students [15]. On one hand the employment may reduce the time available for learning and at the same time could lead to lower educational achievements. But it depends on the intensity of labor market participation (working time). On the other hand, what is more important, the paid employment may improve or develop particular personal characteristics which may have positive impact on school achievements (responsibility, work organization and time management) as a whole.

The way of achieving the money influences the attitude toward money and investment risk. In behavioral finance there is the house money effect [20 21], describes the large or unexpected wealth gains of investors (as the effect of prior outcomes on risky choices) as not their own. The investors are willing to take more risk with it. The similar mechanism may act in the case the other source of "easy achieved money". Therefore the easy way of achieving the money does not facilitate saving them. On the contrary, young people especially who have not experienced work are willing to borrow money for the consumption using credit cards [16].

There are also a lot of possibilities of unearned income like financial income, income from gambling, alimony and social security benefits.

Although the contemporary youth is generally not prepared to complexity of today's financial world, more and more young people are interested in investing. This is result of the promotion the idea of saving and investing money by many stakeholders interested in involving the youth in the financial market.
It also should be mentioned the possibilities of gambling among youth. The gambling is quite popular among teenagers (including university students) who try out different gambling activities, including poker, dice, scratch cards and sports betting.

None, financial income nor gambling and other unearned income will not be considered as the sources of money in considered research; investment, because a very low of percentage of investing students and gambling due to very often accidents of both positive or negative financial results and a lot of identified negative consequences [20] [21]. Also alimony and social security benefits will not be taken into account, because they do not refer to average student.

This paper examines the basic ways of gathering the money by the youth in division into money without doing any work and money for work and the impact of these ways on level of the financial literacy as well as the extent of the financial inclusion.

The paper contributes to the existing literature by analyzing the source of money of Polish higher education students. It also identifies the impact of sources of money gathered by full-time students on financial literacy and financial inclusion. Furthermore, by using the collected data there were comparing the young people studying economic and non-economic areas.

\section{Results of research}

In the research conducted on the base of the questionnaires was collected the data on the source of money, financial literacy, attitude toward risk and on financial inclusion. The respondents were the students of economics and the students of law. The rationale of this division was achieving the data of respondents represent formal financial education (economics students) as well as non-formal and informal financial education (economics and law students).

The study was started by examining the sources of achieving the money. The study has only included the types of sources, without considering the size of the funds raised.

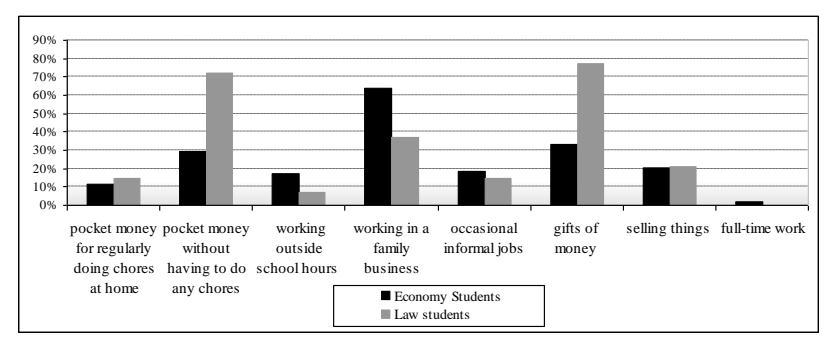

Figure 1. Sources of raising funds by economics and law students in Poland 
Students of different universities raise funds from various sources and mostly from few at a time. The largest number of economics students declared that raise financial funds by working in the family business (64\%), while the largest number of law students declared that raise money from gifts $(77 \%)$ and pocket money without doing any chores $(72 \%)$.

The further analysis includes the division of money sources into three groups:

- only received money without undertaking any work efforts (including pocket money without having to do any chores and gifts of money),

- only money earned in job (including pocket money for regularly doing chores at home, working outside school hours, working in a family business, occasional informal jobs, selling things, full-time work),

- both received money as well as earned in job (at least one items of each above group).

Table 1. Main types of money sources of economics and law students

\begin{tabular}{|l|l|l|l|}
\hline profile of students & $\begin{array}{l}\text { received } \\
\text { money }\end{array}$ & $\begin{array}{l}\text { earned } \\
\text { money }\end{array}$ & $\begin{array}{l}\text { received } \\
\text { and earned }\end{array}$ \\
\hline Economy students & $6,7 \%$ & $53,4 \%$ & $39,9 \%$ \\
\hline Law students & $31,3 \%$ & $7,8 \%$ & $60,9 \%$ \\
\hline
\end{tabular}

There are noted the significant differences in the sources of funds comparing the economics and law students. Less than $7 \%$ of economics students and more than $31 \%$ of the law students declared that the only source of their income are pocket money or/and gifts of money. In contrast, more than $53 \%$ of students of economics and only $7,8 \%$ of students of law declared that their funds come only from their work (including pocket money for regularly doing chores at home). The rest of respondents $(39,9 \%$ economics students, and $60,9 \%$ law students) maintain that their money is partly received and partly earned.

The idea of research was to examine whether the efforts of the undertaken job influence the motivation to financial education which may be measured by level of financial literacy.

Table 2. The relationship between level of financial literacy \& types of money sources

\begin{tabular}{|c|c|c|c|}
\hline $\begin{array}{c}\text { level of financial } \\
\text { literacy }\end{array}$ & $\begin{array}{c}\text { received } \\
\text { money }\end{array}$ & $\begin{array}{c}\text { earned } \\
\text { money }\end{array}$ & $\begin{array}{c}\text { received } \\
\text { and earned }\end{array}$ \\
\hline \multicolumn{4}{|c|}{ Economy Students } \\
\hline $\begin{array}{c}\text { one or none } \\
\text { mistake }\end{array}$ & $63,6 \%$ & $79,3 \%$ & $73,8 \%$ \\
\hline two mistakes & $18,2 \%$ & $17,2 \%$ & $21,5 \%$ \\
\hline $\begin{array}{c}\text { three or more } \\
\text { mistakes }\end{array}$ & $18,2 \%$ & $3,4 \%$ & $4,6 \%$ \\
\hline \multicolumn{4}{|c|}{ Law Students } \\
\hline
\end{tabular}

\begin{tabular}{|c|c|c|c|}
\hline $\begin{array}{c}\text { one or none } \\
\text { mistake }\end{array}$ & $27,8 \%$ & $66,7 \%$ & $50,0 \%$ \\
\hline two mistakes & $44,4 \%$ & $33,3 \%$ & $24,3 \%$ \\
\hline $\begin{array}{c}\text { three or more } \\
\text { mistakes }\end{array}$ & $27,8 \%$ & $0 \%$ & $25,7 \%$ \\
\hline
\end{tabular}

Despite the lower level of financial literacy among respondents representing law students, for each group of students the highest level of financial literacy represent students who raise funds only from the work and the worst results reach students who only receive money (without any work). The effort of undertaken work is likely to result in a certain perception of money and the attitude toward risk. It in turn may directly translate into the scope and scale of participation in the financial market. Therefore, in the following part of the study are verified the relationships between the source of raising funds and the perception of risk associated with the management of available cash resources (investment risk) and between the sources of raising funds and financial inclusion (use of the main financial instruments).

Table 3. The relationship between the source of raising money and attitude toward risk

\begin{tabular}{|c|c|c|c|}
\hline $\begin{array}{l}\text { preferences in } \\
\text { allocation of } \\
\text { the capital }\end{array}$ & $\begin{array}{c}\text { received } \\
\text { money }\end{array}$ & $\begin{array}{l}\text { earned } \\
\text { money }\end{array}$ & $\begin{array}{c}\text { received } \\
\text { and } \\
\text { earned }\end{array}$ \\
\hline \multicolumn{4}{|c|}{ Economy Students } \\
\hline $\begin{array}{l}50 \% \text { bonds, } \\
50 \% \text { stocks }\end{array}$ & $18,2 \%$ & $25,3 \%$ & $30,8 \%$ \\
\hline $\begin{array}{l}\text { More than } \\
50 \% \text { bonds } \\
\text { and less than } \\
50 \% \text { stocks }\end{array}$ & $9,1 \%$ & $40,2 \%$ & $36,9 \%$ \\
\hline Only bonds & $0,0 \%$ & $17,2 \%$ & $13,8 \%$ \\
\hline Only stocks & $72,7 \%$ & $14,9 \%$ & $15,4 \%$ \\
\hline $\begin{array}{c}\text { No } \\
\text { preferences }\end{array}$ & $0,0 \%$ & $2,0 \%$ & $3,0 \%$ \\
\hline \multicolumn{4}{|c|}{ Law Students } \\
\hline $\begin{array}{l}50 \% \text { bonds, } \\
50 \% \text { stocks }\end{array}$ & $16,7 \%$ & $44,4 \%$ & $38,6 \%$ \\
\hline $\begin{array}{c}\text { More than } \\
50 \% \text { bonds } \\
\text { and less than } \\
50 \% \text { stocks }\end{array}$ & $38,9 \%$ & $22,2 \%$ & $20,0 \%$ \\
\hline Only bonds & $8,3 \%$ & $11,1 \%$ & $12,9 \%$ \\
\hline Only stocks & $8,3 \%$ & $22,2 \%$ & $11,4 \%$ \\
\hline $\begin{array}{c}\text { No } \\
\text { preferences }\end{array}$ & $27,8 \%$ & $0,0 \%$ & $17,0 \%$ \\
\hline
\end{tabular}

The analysis of the dependence of sources of funds on attitude toward risk among students also allows spotting the specific regularities and drawing some conclusions. The greatest rationality in the attitude 
toward risk represents students who raise the funds from gainful employment. Respondents in this group strongly prefer a moderate level of the risk, and recognize the advantages of diversification of the investment portfolio. The evidence of this is also the lowest percentage of people in this group who can not identify their preferences.

Table 4. The relationship between the source of fundraising and the degree of participating in the financial market

\begin{tabular}{|c|c|c|c|}
\hline $\begin{array}{c}\text { degree of } \\
\text { financial inclusion } \\
\text { (last } 12 \text { months) }\end{array}$ & $\begin{array}{c}\text { received } \\
\text { money }\end{array}$ & $\begin{array}{l}\text { earned } \\
\text { money }\end{array}$ & $\begin{array}{c}\text { received } \\
\text { and } \\
\text { earned }\end{array}$ \\
\hline \multicolumn{4}{|c|}{ Economy students } \\
\hline banking account & $100 \%$ & $95 \%$ & $91 \%$ \\
\hline payment card & $64 \%$ & $92 \%$ & $91 \%$ \\
\hline more than 1 card & $9 \%$ & $5 \%$ & $11 \%$ \\
\hline any savings & $91 \%$ & $95 \%$ & $92 \%$ \\
\hline savings in the bank & $64 \%$ & $84 \%$ & $80 \%$ \\
\hline $\begin{array}{l}\text { borrowing from } \\
\text { friends or family }\end{array}$ & $18 \%$ & $23 \%$ & $18 \%$ \\
\hline loan from bank & $0 \%$ & $9 \%$ & $8 \%$ \\
\hline risky investment & $9 \%$ & $9 \%$ & $11 \%$ \\
\hline $\begin{array}{l}\text { at least one form of } \\
\text { mobile payment: } \\
\text { pay bills or send } \\
\text { money or receive } \\
\text { money }\end{array}$ & $100 \%$ & $76 \%$ & $69 \%$ \\
\hline $\begin{array}{l}\text { all forms of mobile } \\
\text { payment: pay bills } \\
\text { and send money and } \\
\text { receive money }\end{array}$ & $55 \%$ & $52 \%$ & $38 \%$ \\
\hline \multicolumn{4}{|c|}{ Law students } \\
\hline banking account & $89 \%$ & $89 \%$ & $83 \%$ \\
\hline payment card & $69 \%$ & $67 \%$ & $67 \%$ \\
\hline more than 1 card & $6 \%$ & $11 \%$ & $4 \%$ \\
\hline any savings & $94 \%$ & $100 \%$ & $97 \%$ \\
\hline savings in the bank & $83 \%$ & $89 \%$ & $74 \%$ \\
\hline $\begin{array}{l}\text { borrowing from } \\
\text { friends or family }\end{array}$ & $19 \%$ & $22 \%$ & $19 \%$ \\
\hline loan from bank & $0 \%$ & $0 \%$ & $0 \%$ \\
\hline risky investment & $3 \%$ & $22 \%$ & $7 \%$ \\
\hline $\begin{array}{c}\text { at least one form of } \\
\text { mobile payment: } \\
\text { pay bills or send } \\
\text { money or receive } \\
\text { money }\end{array}$ & $72 \%$ & $78 \%$ & $71 \%$ \\
\hline $\begin{array}{l}\text { all forms of mobile } \\
\text { payment: pay bills } \\
\text { and send money and } \\
\text { receive money }\end{array}$ & $22 \%$ & $33 \%$ & $36 \%$ \\
\hline
\end{tabular}

Those who have received the money without any work (especially students of economics) are more willing to invest their assets in risky investments and less willing to diversify the investment portfolio. But it should be noted these are rather preferences which are not confirmed by investment activities especially the risky one, due to the limited financial sources of young people.

Regardless of the area of study, students who raising the money only by working more often keep the money and represent less propensity to consume it. They are also more likely to save earned money in the banks (or other formal institutions). But there were neither the evident regularities in terms of investment risk - probably because of the low percentage of respondents who invest in risky assets nor regularities in the use of mobile payments.

In terms of borrowing money, the typical seem to be more frequent loans from family and friends in case people working. However, there is no regularity in terms of bank loans. This fact can be justified like in the case of risky investments by a small percentage of respondents using these loans, surely due to the lack of credit worthiness. By analyzing the various aspects of the financial education it should be noted that not all people have the opportunity to use formal education in this area, hence, the role and importance of non-formal and informal learning (e.g. self education and learning by doing).

Highlighting the importance of the level of financial literacy in today's societies, it should be paid attention to the usage of modern technology especially the Internet in non-formal and informal education. That is why there were examined in the research the extent and at the same time the possibilities of using the Internet in non-formal and informal education including the financial education by practice.

Table 5. The usage the Internet in achieving or expanding knowledge (also financial)

\begin{tabular}{|c|c|c|c|}
\hline Internet usage & $\begin{array}{c}\text { received } \\
\text { money }\end{array}$ & $\begin{array}{l}\text { earned } \\
\text { money }\end{array}$ & $\begin{array}{c}\text { received } \\
\text { and } \\
\text { earned }\end{array}$ \\
\hline \multicolumn{4}{|l|}{ Economy students } \\
\hline $\begin{array}{l}\text { educational } \\
\text { contents are not } \\
\text { directly related to } \\
\text { the fields of study }\end{array}$ & $100 \%$ & $99 \%$ & $100 \%$ \\
\hline $\begin{array}{l}\text { using the Internet } \\
\text { for comparing } \\
\text { offers of financial } \\
\text { market }\end{array}$ & $82 \%$ & $91 \%$ & $88 \%$ \\
\hline \multicolumn{4}{|l|}{ Law students } \\
\hline $\begin{array}{l}\text { educational } \\
\text { contents are not } \\
\text { directly related to } \\
\text { the fields of study }\end{array}$ & $97 \%$ & $100 \%$ & $96 \%$ \\
\hline $\begin{array}{l}\text { using the Internet } \\
\text { for comparing } \\
\text { offers of financial } \\
\text { market }\end{array}$ & $67 \%$ & $56 \%$ & $76 \%$ \\
\hline
\end{tabular}


The work effort and associated with this the approach to the money may motivate people to reach the additional knowledge on finance. In the research there were verified the scope of Internet usage in the obtaining and expanding the financial knowledge.

In general, the usage of the Internet is different in researched groups of university students, probably due to the specificity of these areas. So the situation may be the result of the habits and patterns. On the other hand there is a lot to do. First of all, it should be realize the role, meaning and the ease of using the Internet in educational process as well as the benefits of such education possibilities. It is evident that the potential of the Internet in education is not fully exploited, especially in the financial education of students of uneconomical fields.

\section{Conclusions}

The most important conclusion of the conducted research is that source of raising funds definitely influences the results of financial education. The labor experience has positive impact on the level of the financial literacy and inclusion. That's why the education is one of the best investment students can make. It refers to all kind of education (formal, nonformal and informal) in each area including finance. Working university students usually represent higher level of financial literacy and more frequent use a savings account and other financial instruments. The important feature of this group of students is greater rationality in the attitude toward money and associated risk as well as more frequent undertaking the efforts of alternative form of education, e.g. nonformal and informal financial education via Internet. However, it should be remembered that level of financial literacy and financial inclusion is not satisfactory as a whole. In such situation very important are all insights that may improve the efficiency of financial education.

The positive impact of work undertaken on attitude towards money as the motivation to be smarter in finance should be promoted among parents and among youth to be aware these dependencies and relationships. The earning money in contrary to money for nothing may helps young people in gradually taking on more responsibility for their own money. The students should be also aware that their current approach to money is likely to have a direct effect on ability to live independently in the future. And for parents and other entities responsible for effects of financial education very important is understanding of young people's attitudes, and the influences on those attitudes towards work and money.

\section{References}

[1] J. Almenberg, A. Dreber "Gender, Stock Market Participation and Financial Literacy”, SSE/EFI Working Paper Series in Economics and Finance No 737, 2012.

[2] A. Atkinson, "Financial Capability Amongst Adults with Literacy and Numeracy Needs", Personal Finance Research Centre, University of Bristol, Bristol, 2007, p.41.

[3] A. Atkinson, F. Messy, "Measuring Financial Literacy: Results of the OECD/INFE Pilot Study", Working Papers on Finance, Insurance and Private Pensions, No. 15, 2012, pp.446-448, OECD Publishing.

[4] S. Bauhoff, K.G.Carman, A.Wuppermann, "Financial Literacy and Consumer Choice of Health Insurance, Evidence from Low-Income Populations in the United States", RAND Labor \& Population, Working Paper, Santa Monica, 2013.

[5] J. Bonke, "Do Danish children and young people receive pocket money?", The Rockwool Foundation Research Unit, Study Paper No. 57, Copenhagen 2013,

[6] C.Bumcort, J.Lin and A.Lusardi, "The Geography of Financial Literacy: A Report”, Financial Literacy Center. 2011, p.10.

[7] S. Fernandez-Lopez, L.Otero, M.Vivel and D.Rodeiro "What Are the Driving Forces of Individuals' Retirement Savings?", Finance a úvěr-Czech Journal of Economics and Finance, no. 32010 , pp. 226-251,

[8] R.Fonseca, K.Mullen, G.Zamarro, J.Zissimopoulos, "What Explains the Gender Gap in Financial Literacy? The Role of Household Decision-Making", RAND Labor and Population, Working Paper, Santa Monica, 2010.

[9] B.Frączek, "National Strategies for Financial Education -the concept and first experiences in the Word", Oeconomia, (Eds.) J.Węcławski, UMC, Lublin, 2013, pp.25-33.

[10] B. Frączek, "Niski poziom alfabetyzacji finansowej społeczeństwa - jako bariera ograniczająca rozwój rynku kapitałowego"(,,The low level of financial literacy of society - as a barrier to the development of the capital market") [in:] Rynek kapitałowy wobec wyzwań dekoniunktury, Wydział Zarządzania UW Warsaw, 2014.

[11] B.Frączek,, M.Klimontowicz, "Financial literacy and its influence on young customers' decision factors", Journal of International Management, Vol 3, no1, 2015.

[12] A.Hung, J. Yoong and E. Brown, "Empowering Women Through Financial Awareness and Education", OECD Working Papers on Finance, Insurance and Private Pensions, No. 14, OECD Publishing, 2012.

[13] A.Lusardi and O.S.Mitchell, "Financial literacy around the world: an overview" Journal of Pension Economics and Finance, Vol. 10, No. 4, 2011, pp.497-508 
[14] A.Lusardi, O.S.Mitchell and V.Curto, "Financial literacy among the young", Journal of Consumer Affairs, Vol. 44, No. 2, 2010, pp.358-380.

[15] MAS "It's time to talk: young people and money regrets”, Money Advice Service, London, 2014.

[16] M.Rokicka "The impact of students' part-time work on educational outcomes, Institute for Social \& Economic Research", ISER Working Paper Series, Educational Research Institute, Nr 42, 2014.

[17] G.Simmel, The Philosophy of Money, Routledge \& Kegan Paul, London, 1997.

[18] L. Spataro, L. Corsini, "Endogenous Financial Literacy, Saving and Stock Market Participation", MPRA, Paper No. 44342, 2013.

[19] R.M.Taneja, "Money Attitude - an abridgment", Journal of Arts, Science \& Commerce, Vol. III, Issue3(3), 2012, pp.94-98.

[20] R.Thaler, E. Johnson, "Gambling With the House Money and Trying to Break Even: The Effects of Prior Outcomes on Risky Choice", Management Science, 36(6), 1990, pp.643-660.

[21] R.J. Williams, J.Rehm, and R.G.M.Stevens, "The Social and Economic Impacts of Gambling. Final Report" prepared for the Canadian Consortium for Gambling Research. March 11, 2011.

[22] L. Xu, and B.Zia, "Financial Literacy around the Word", Policy Research, Working Paper 6107, The World Bank Development Research Group, 2012. 